\title{
Staff's Perceptions of Vision and Long Term Principal Leadership in South African schools: An Exploratory Study
}

\author{
EJ van Niekerk \\ Department of Educational Leadership and Management \\ University of South Africa \\ vniekej@unisa.ac.za \\ Micheal M van Wyk \\ Department of Curriculum and Instructional Studies \\ University of South Africa \\ vwykmm@unisa.ac.za
}

\section{Doi:10.5901/mjss.2014.v5n4p406}

\begin{abstract}
This article reports on the perceptions of school staff on vision as part of the long term leadership task of their principals. A quantitative study was conducted using the long term leadership model as a theoretical framework to guide the compilation of the long term leadership questionnaire. This investigation showed that the majority of respondents agree that vision is an important determinant of long term leadership in schools. Vision impacts on the involvement of stakeholders, the effectiveness of school management and the quality of teaching and learning. Another finding was that respondents' perceptions of the vision of their school principals has statistically significant correlations in relation to vision communication, values management, staff development and empowerment as factors which also impact on long term leadership provision in schools. These findings have significant implications for the development of long term leadership training materials for principals.
\end{abstract}

Keywords: envisioning, long term leadership, principal leadership, perceptions of vision, leadership tasks.

\section{Introduction}

John F Demartini provides some powerful ideas about the role of vision that can be applied to the functioning of leaders, and to school principals as educational leaders. According to him, "The breadth of your vision determines the quality of your life, and the effect you have on the world." (Demartini 2002, p92). He (Demartini 2002) reckons that leaders grow when they serve a cause bigger than themselves, and their sources grow as they themselves grow and expand their visions. Demartini (2008b) says that a magnetic personality emanates from a leader that is inspired and has a clear vision. According to him (Demartini 2002) the clarity of the vision makes it easier to realise in spite of challenges that might be experienced by leaders, and the vitality and energy of leaders are directly related to their vision. A clear vision also incorporates a message that filters through to the followers of leaders (Demartini 2008b). These ideas and those of prominent leadership theorists, such as Warren Bennis (Crainer and Dearlove 2003; Bass 2008), attest to the important role ascribed to vision in the functioning of leaders.

Vision is intricately tied to the long term dimension of leadership. A vision deals with the future that is envisioned (Bass 2008; Sterling and Davidoff 2000). In schools principals are the leaders who need to collaboratively with their followers visualise the future, establish, communicate and realise the vision of the school (Van Niekerk 2012).

However, in the light of the failure of the South African education system to provide an acceptable throughput rate, and because of the poor performance of South African learners in international achievement tests (http://mg.co.za/article/2011-04-08-sa-education-the-poorest-choice/), one may rightfully question how principals perform in relation to realising their schools' vision as the encompassing task of long term leadership.

Moreover, in the Report of the Task Team on Education Management (1996) the South African Department of Education states that the emphasis in schools at the time was on short term tasks and that there is a limited awareness of the potential for planning. One may rightfully also in the light of the above question the quality of the visualising abilities of principals. This is rather disconcerting in the light of the international move towards school based management (Botha 2004) and because leadership is largely about ensuring a clear and shared sense of the future direction to be taken 
(Bush and Thurlow 2003). The research for this article in an exploratory way shreds light on the current position in South African schools regarding envisioning as a long term leadership task of principals. Quantitative studies of the perceptions of school staff and managers on principals' long term leadership provision as defined in this article, and particularly envisioning as an important aspect thereof, do not exist.

The encompassing aim of the research project of which this article forms a part, was to determine the perceptions amongst school staff of the long term school principal leadership provision in South African schools. This article reports on the perceptions of school staff on envisioning as a long term leadership task of their principals.

Consecutively in this article the role of vision in the long term leadership provision of the principal is contextualised with reference to relevant literature, followed by a discussion of the theoretical framework, the methodology employed, and the results of the empirical study.

\section{Literature Review}

\subsection{The role of vision in long term leadership}

The functioning of school principals as leaders is directly affected by their vision for their schools and the manner in which they fulfil this vision (Bass 2008; Bush 2007). The nature of the principal's leadership relates strongly to reaching the vision of the school as the vision is supposed to focus all activities and stakeholders in the school on the realisation thereof (Crainer and Dearlove 2003; Masuku 2012). As such all stakeholders should know the vision and be inspired by it. The vision determines the future of the school because the development, communication and accomplishment of the vision is not only the principal's most important task, but directly relates to the image of what is going to happen in the future of the school (Sterling and Davidoff 2000; McEwan 2003). The vision as the overarching driving force of an organisation such as a school also provides guidance regarding practical activities, such as resources allocation, staff deployment, organising schedules, professional development priorities, and decision making about matters relating to the core function of teaching and learning (Murphy and Lick 2005; Botha 2004). It is therefore of compelling importance that the principal be enthusiastic about and inspired by the vision of the school (Bass 2008; Masuku 2012). The vision of the school is important because it focuses everything on the core function of the school, which is effective teaching and learning. This is actually what principals should be passionate about and perceive as their guiding star amid all the hustle and bustle of being a leader of a school. The vision should in fact be the guiding star in all school activities binding them to the core task of teaching and learning. In the mind of the principal as authentic leader the vision thus fulfils an essential integrating function providing focus on the core task of the school (Masuku 2012; Van Niekerk 2012b).

In the light of the above, vision can be linked to change, as it encompasses the image towards which the leader needs to direct the school (Van Niekerk and Van Niekerk 2009: Bass 2008). The school leader drives the change inherently implied by the vision together with the stakeholders. The process of vision formulation, vision communication and vision accomplishment should thus be a collaborative process growing from the educational desire of the school community, and involving all relevant stakeholders (Masuku 2012; Botha 2004).

In a study by Van Niekerk (2012a) within a particular South African educational setting it emanated that stakeholders' identification with the vision is problematic in instances where stakeholders do not form a meaningful part of the vision formulation process; where parents are apathetic; where the vision is out of date or needs to be refined; where education department officials require visions but stakeholders do not feel the need for it; and where the vision is not well communicated. Having and fulfilling a vision is thus not a superficial challenge that principals need to comply with; it is a time consuming, collaborative process requiring energetic input (Sterling and Davidoff 2000).

Some characteristics that a good vision should conform to apart from being collaboratively designed, are that it should be inspiring, challenging, and realistic, being based on the current position of the school (derived from a selfevaluation or external evaluation regarding teaching and learning in the school) as well as where the school would like to be at some future point in time (Van Niekerk 2012b). In the study mentioned above (Van Niekerk 2012a) it emanated that though schools do have vision statements, there are concerns associated with the formulation process and the communication of their visions, which in many instances makes the provision of effective long term leadership problematic.

In the theoretical framework guiding the research for this article, vision is placed firmly within the long term dimension of the principal's leadership task. It in fact encompasses all the leadership functions that the principal needs to perform to be successful in the long term. 


\subsection{Long term leadership theoretical framework}

The research for this article was done as part of a larger research project investigating perceptions of school staff on the nature of the long term leadership provided by the school principal. The long term leadership model of Van Niekerk (1995) was used as the theoretical framework to place the research within an authentic leadership context and to guide the compilation of the quantitative questionnaire to determine the perceptions of school staff.

In this model two facets of the long term leadership task of the principal are identified. The first relates to the creation of desirable conditions under which staff can excel (Van Niekerk 1995). The tasks relating to this facet are vision creation, vision communication and values management by which the school culture is built up. The second facet relates to the leader performing the leadership tasks of training, development and empowerment of personnel. All the above leadership tasks are actually encompassed by the inspirational vision of the leader (Van Niekerk 1995). The essence of leadership relates to influencing people (Kleon and Rinehart 1998; Harris and Muijs 2005), and this influencing is a vision-driven process encompassing both the facets mentioned above (Van Niekerk 1995). These above leadership tasks/functions are well described in management literature (Bass 2008; Javidan, Dorfman, Howell and Hanges 2010; Coleman 2003; Bush and Anderson 2003; Mosoge 2008; Naidu, Joubert, Mestry, Mosoge, and Ngcobo 2008; Steyn 2012; Van Niekerk 1995). Moreover, the model of long term leadership as described by Van Niekerk (1995; 2006; 2008; 2012a; 2012b; Van Niekerk and Dube 2011, Van Niekerk and Van Niekerk 2006, Van Niekerk and Van Niekerk 2009) was considered appropriate to use in the compilation of the questionnaire. The model is provided below in Figure 1.

With reference to Figure 1, vision is depicted as the encompassing leadership task that together with the other leadership tasks promote the two facets of long term leadership referred to above. These facets are: creating the circumstances under which followers can excel (through envisioning, vision communication and values management), and enabling followers to excel by fulfilling the tasks of training, development and empowerment. The importance of vision in long term leadership effectiveness is evidently highlighted in Figure 1.

\section{A MODEL FOR LONG-TERM EFFECTIVE LEADERSHIP}

\section{Research Methodology}

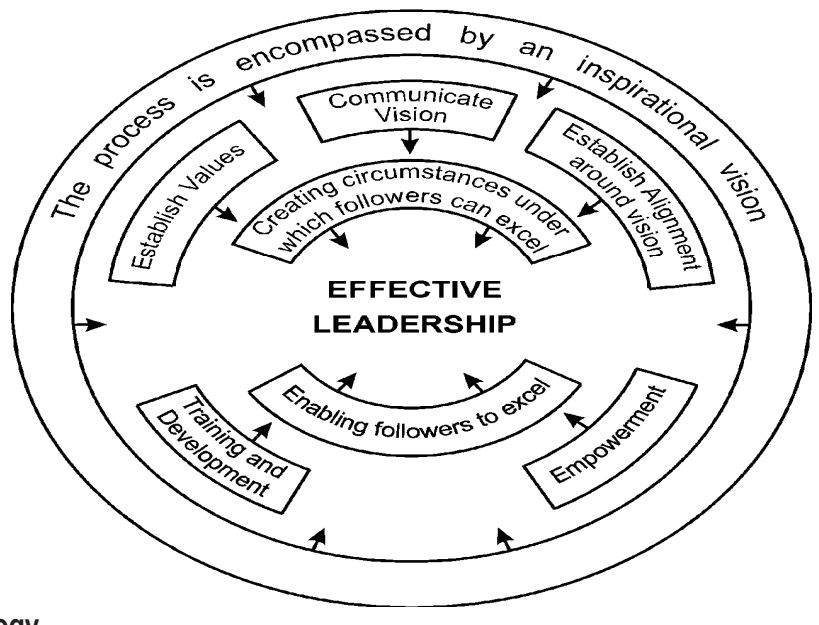

\subsection{Research design}

For the purpose of this study a quantitative research design was employed in order to involve as many respondents as possible of the chosen population, and because a mailed questionnaire was the only way to involve the chosen population as they were scattered in schools all over the country. The long term leadership tasks identified above were the focus of a questionnaire that was despatched to the sample population by mail in 2011. It is an exploratory study because the researchers are not aware of similar studies situating vision within the long term leadership provision of principals, and because the number of respondents involved does not qualify it as a large scale research project. 


\subsection{Sampling}

The population who were targeted for completion of the questionnaire were 410 Unisa students who were registered for the Course in School Management in the Centre for Community Training and Development in respectively 2009 (131 students), 2010 (176 students) and 2011 (131 students). They were considered to be ideal respondents to provide information on their perceptions of the long term dimension of school principal leadership in their respective schools as they not only completed tasks on long term leadership during their in-service studies, but also on vision building specifically. The tasks on long term leadership focused on understanding the model and improving their leadership utilising the model. They also had to apply the process of vision communication and vision building in relation to the model. Of this sample population one hundred and eighteen (118) returned their questionnaires. (The researchers had no certainty whether the students registered in 2009 and 2010 were still resident at the addresses that they had available, as some could have been promoted to other locations, deceased, left the profession or their resident addresses with a resultant change in postal addresses; so the researchers were satisfied with the number returned).

\subsection{Data collection instrument}

The questionnaire consisted of Section A and Section B. In Section A the biographical data was requested from the respondents. In Section B items covered the perceptions of respondents as agreement ratings on a four point Likert rating scale on five long term leadership tasks identified in the model of long term leadership (namely vision, vision communication, values management, staff development and empowerment) that was chosen as theoretical framework for the study. The concept of vision was covered in a subset of 10 items, which is the subset reported on in this article. The items focused on the most important aspects of vision in relation to long term leadership covered in paragraph 4.2 in this article. The reliability of the questionnaire was calculated with Cronbach's alpha internal consistency coefficient, which was well above the reliability score $(\alpha=0.7)$ on all five of the long term leadership tasks in the questionnaire for this study. Descriptive and inferential data was computed in table formats.

\subsection{Ethical considerations}

Respondents were assured that their responses would be treated confidentially, that it would be used only for research purposes, and that anonymity would be guaranteed. Completion of the questionnaire was voluntary.

\section{Results and Discussion}

\subsection{Biographical information}

Section A of the questionnaire provided biographical information on the respondents.

Male respondents were $58.0 \%$ compared to female respondents (42.0\%). The majority of respondents (58.8\%) fall within the age category $40-49$ years. Even though $42 \%$ of the respondents were educators, the majority of the respondents occupied managerial posts consisting of Heads of Departments (25.2\%), Principals (18.5\%) and Deputy Principals (14.3\%). Furthermore the majority of respondents were qualified with a diploma (52\%), secondly with a degree plus diploma (25\%), followed by BEd Hons (21\%) and lastly, a MEd qualification (2\%). The vast majority of respondents have more than 10 years teaching experience. The vast majority also have relevant management qualifications (94\%), while $83,9 \%$ have some form of education management experience. The most of the respondents teach in rural areas (68\%), while $19,4 \%$ are stationed in township schools and $12,6 \%$ work in city or town schools.

\subsection{Perceptions of vision as a long term leadership task}

Section B of the questionnaire dealt with long term leadership in five sub-sections, namely vision (10 questions), vision communication (12 questions), values management (30 questions), staff development (21 questions), and empowerment (16 questions). Perceptions on these leadership functions were tested on a four point Lickert scale determining respondent agreement to statements according to the following satisfaction scale: strongly agree (SA), agree (A), disagree (DA), and strongly disagree (SD). Tables 2-4 provide a summary of available information on the perceptions of the respondents in this case study. 
Table 2: Means and standard deviation (SD) for vision as long term leadership task ( $\mathrm{N}=118)$

\begin{tabular}{|c|c|c|c|c|c|c|}
\hline Item statements on vision & Mean & SD & $\begin{array}{c}4 \\
S A\end{array}$ & $\begin{array}{l}3 \\
\text { A }\end{array}$ & $\begin{array}{c}2 \\
\mathrm{DA}\end{array}$ & $\begin{array}{c}1 \\
\text { SD }\end{array}$ \\
\hline \multirow{2}{*}{ The vision of the school focuses on effective teaching and learning. } & \multirow{2}{*}{3.18} & \multirow{2}{*}{2.11} & 40 & 39 & 21 & 10 \\
\hline & & & 36.5 & 35.5 & 19.0 & 9.0 \\
\hline \multirow{2}{*}{$\begin{array}{l}\text { All stakeholders (staff, administrative staff, school governing body, parents, and learners in } \\
\text { the case of secondary schools) were involved in the formulation of the vision. }\end{array}$} & \multirow{2}{*}{3.86} & \multirow{2}{*}{3.81} & 52 & 55 & 6 & 6 \\
\hline & & & 43.7 & 46.3 & 5.0 & 5.0 \\
\hline \multirow{2}{*}{ The staff knows the vision of the school. } & \multirow{2}{*}{3.37} & \multirow{2}{*}{2.56} & 37 & 63 & 12 & 6 \\
\hline & & & 31.4 & 53.4 & 10.2 & 5.0 \\
\hline \multirow{2}{*}{ The staff supports the vision of the school. } & \multirow{2}{*}{3.59} & \multirow{2}{*}{3.77} & 34 & 66 & 14 & 4 \\
\hline & & & 29.6 & 54.8 & 12.2 & 3.4 \\
\hline \multirow{2}{*}{ Our vision serves as guiding star in all school activities. } & \multirow{2}{*}{2.67} & \multirow{2}{*}{7.22} & 11 & 37 & 45 & 20 \\
\hline & & & 9.7 & 32.7 & 39.9 & 17.7 \\
\hline \multirow{2}{*}{ The principal makes too much of a fuss about the school's vision. } & \multirow{2}{*}{3.09} & \multirow{2}{*}{1.46} & 46 & 48 & 17 & 6 \\
\hline & & & 39.4 & 41.1 & 14.5 & 5.0 \\
\hline \multirow{2}{*}{ The true nature of our principal's leadership is to reach the vision of our school. } & \multirow{2}{*}{3.27} & \multirow{2}{*}{4.22} & 40 & 55 & 17 & 7 \\
\hline & & & 33.9 & 46.6 & 14.5 & 5.0 \\
\hline \multirow{2}{*}{ The focus of our principal is to make everything happen according to the rules. } & \multirow{2}{*}{3.83} & \multirow{2}{*}{3.81} & 57 & 53 & 16 & 1 \\
\hline & & & 48.4 & 44.9 & 13.7 & 1.0 \\
\hline \multirow{2}{*}{ Our vision determines our future. } & \multirow{2}{*}{3.78} & \multirow{2}{*}{3.88} & 49 & 51 & 11 & 6 \\
\hline & & & 41.9 & \begin{tabular}{|l|}
43.7 \\
\end{tabular} & 9.4 & 5.0 \\
\hline \multirow{2}{*}{ The principal is enthusiastic about the school's vision. } & \multirow{2}{*}{2.97} & \multirow{2}{*}{1.44} & 22 & 54 & 33 & 8 \\
\hline & & & 18.8 & 46.2 & 28.2 & 6.8 \\
\hline
\end{tabular}

Based on the data in Table 2, the majority of respondents "strongly agree" to "agree" (thus a positive response) that the vision of their school focuses on effective teaching and learning (72\%); that all stakeholders were involved in the formulation of the vision (90\%); that the staff knows the vision of the school $(84,4 \%)$; that the staff supports the vision of the school $(84,4 \%)$; that the true nature of their principal's leadership is to reach the vision of the school $(80,5)$; and that the vision of the school determines the future of the school $(85,6 \%)$. The perception scores indicate that these important aspects of envisioning covered in the literature study earlier on are actually adhered to by most principals. This portrays a positive picture from which one may derive that respondents agree that the vision in their schools is an important determinant of long term leadership with an impact on the involvement of stakeholders, the nature of school management and the quality of teaching and learning. This is an encouraging finding. However, findings on respondent perceptions in the above table also indicate that there are respondents who do not agree to the above aspects stressed in the literature study, and in some instances the percentage is relatively high (as in the case of $28 \%$ not agreeing with the statement that the vision of the school focuses on effective teaching and learning).

To the above negative trend can be added that $42,4 \%$ of the respondents indicated that the vision does not serve as a guiding star in all school activities. In the literature study it was emphasised that the vision should be the guiding star in all school activities binding them to the core task of teaching and learning. If one adds to this that $93,3 \%$ also indicated that the focus of their principal is to make everything happen according to the rules, it seems as if many principals function as managers in a bureaucratically governed system (the South African state schools) rather than visionary leaders that can bring about the changes needed in South African state schools. The item The focus of our principal is to make everything happen according to the rules was deliberately included to determine where the real focus of principals lie. The researchers did not in the analysis take into account the statement: The principal makes too much of a fuss about the school's vision, because they believe that this item could have been interpreted in various ways by the respondents, and that it would be better to omit it from the analysis.

A further indication of a problem situation is that only $65 \%$ of respondents indicated that the principal is enthusiastic about the school's vision, while it was stressed in the literature study that principals need to be enthusiastic about the vision. The total of $35 \%$ of principals not being enthusiastic about their school's vision indicates that there is a divide between theory and practice on the role of vision in long term leadership.

One can thus deduce that in spite of overall positive trends emanating from Table 2 regarding respondent perceptions of the nature of principals' execution of vision as a long term leadership task, there are also cautionary trends that are indicative of the true situation regarding vision implementation in schools which accord with an earlier study by Van Niekerk (2012a). There are schools with principals lacking the basic knowledge and skills required to 
succeed in the vision formulation and implementation process discussed in the literature study and employed in the formulation of the questionnaire. This is not so encouraging regarding the nature of envisioning as an important long term leadership task, which actually encompasses the other long term leadership tasks, as indicated in Figure 1. Significant trends emanating from the research on the interrelation between vision and long term leadership will further be explored by means of inferential statistics.

\subsection{The interrelation between vision and other long term leadership tasks}

In this section the effect size of vision on long term leadership is explored. Table 3 indicates the mean and standard deviation scores.

Table 3: Mean and standard deviation on the effect size of vision on long term leadership

\begin{tabular}{|c|l|c|c|c|c|}
\hline \multirow{2}{*}{ The importance of vision } & \multicolumn{3}{|c|}{ Respondents } & \multicolumn{3}{c|}{ Group statistics } \\
\hline \multirow{3}{*}{ The importance of vision as a long term leadership task } & Who are you? & $\mathrm{N}$ & Mean & SD & SE mean \\
\cline { 2 - 6 } & Principal & 22 & 3.1 & 2.091 & 0.211 \\
\cline { 2 - 6 } & Teachers and other managers & 96 & 3.8 & 2.641 & 0.189 \\
\hline
\end{tabular}

Table 4 below provides an independent sample test comparing principals to other managers' and teachers' perceptions of long term leadership.

Table 4: Independent sample t-test comparing principals' and teachers' perceptions on long term leadership.

\begin{tabular}{|c|c|c|c|c|c|c|c|c|c|c|}
\hline \multicolumn{11}{|c|}{ Independent sample test } \\
\hline & & \multicolumn{2}{|c|}{$\begin{array}{l}\text { Levene's test for } \\
\text { equality of } \\
\text { variances }\end{array}$} & \multicolumn{5}{|c|}{ t-test for equality of means } & \multicolumn{2}{|c|}{$\begin{array}{l}95 \% \text { confidence } \\
\text { interval of the } \\
\text { difference }\end{array}$} \\
\hline & & $\mathrm{F}$ & Sig. & $T$ & Df & $\begin{array}{c}\text { Sig. } \\
(2- \\
\text { tailed) }\end{array}$ & $\begin{array}{c}\text { Mean } \\
\text { difference }\end{array}$ & $\begin{array}{c}\mathrm{SE} \\
\text { difference }\end{array}$ & Lower & upper \\
\hline \multirow{2}{*}{$\begin{array}{l}\text { The importance of } \\
\text { vision as a task of } \\
\text { long term } \\
\text { leadership }\end{array}$} & $\frac{\text { PrincipalsEqual }}{\text { variances assured }}$ & 8.322 & 0.004 & 1.934 & 998 & $0.005^{* \star}$ & 3.1 & 0.155 & -0.006 & 0.602 \\
\hline & $\begin{array}{l}\text { Other managers and } \\
\text { teachers } \\
\begin{array}{l}\text { Equal variances not } \\
\text { assured }\end{array} \\
\end{array}$ & & & 2.022 & 811.771 & $0.002^{\star \star}$ & 3.9 & 0.148 & 0.098 & 0.056 \\
\hline
\end{tabular}

$$
{ }^{\star \star} p \leq .05
$$

Information in Table 3 shows calculations regarding effect size of vision on long term leadership. Furthermore, a sample t-test was computed to compare principals' and other managers' and teachers' perceptions on long term leadership (Table 4). Results in Table 4 show that there are differences in the mean scores of other managers' and teachers' perceptions as a group ( $M=3.9, S E=0.148)$ compared to the principals $(M=3.1, S E=0.155)$ in relation to vision in enhancing long term leadership. The score in Table 4 is statistically significantly higher in a two-tailed test for other managers and teachers compared to principals. Overall, the results show that other managers and teachers were more explicit on the importance of a vision as compared to principals regarding sustainable long term leadership in schools.

Table 5: Internal reliability, correlations, means and standard deviation on vision in relation to values management, vision communication, staff development and empowerment.

\begin{tabular}{|c|l|c|c|c|c|c|c|}
\hline \multicolumn{2}{|c|}{ Scales } & $\mathrm{a}=0.7$ & 1 & 2 & 3 & 4 & 5 \\
\hline 1 & Vision & 0.79 & 1 & & & & \\
\hline 2 & Vision communication & 0.88 & $0.56^{\star}$ & 1 & & & \\
\hline 3 & Values management & 0.78 & 0.24 & $0.48^{\star}$ & 1 & & \\
\hline 4 & Staff development & 0.87 & 0.33 & 0.23 & 0.26 & 1 & \\
\hline 5 & Empowerment & 0.83 & 0.22 & 0.19 & $0.38^{\star}$ & $0.51^{*}$ & 1 \\
\hline
\end{tabular}




\begin{tabular}{|c|c|c|c|c|c|c|}
\hline Mean & & 3.69 & 3.49 & 3.41 & 3.05 & 3.15 \\
\hline SD & & 0.73 & 0.89 & 0.58 & 0.48 & 0.68 \\
\hline
\end{tabular}

As seen in Table 5 the reliability test, Cronbach's alpha internal consistency coefficient, was well above the reliability score $(\alpha=0.7)$ on all five of the long term leadership tasks in the questionnaire for this study. The reliability scores indicate that all five items are highly reliable in terms of long term leadership tasks.

As with vision, respondents also considered vision communication as very important to advance long term leadership ( $M=3.69, S D=0.73)$ as compared to values management $(M=3.49, S D=.89)$. Examination of respondents' perceptions of how vision influences long term leadership in relation to their perceptions of staff development $(\mathrm{M}=3.41$, $\mathrm{SD}=0.58)$ and their perceptions of empowerment indicated a moderate relation $(M=3.05, \mathrm{SD}=0.48)$.

In order to investigate whether any correlation existed between the respondents' perceived views of vision, vision communication, staff development and empowerment, Pearson correlation coefficients were also computed. Respondents' perceptions of vision had statistically significant correlations with vision communication $(r(118)=.56$, $p<.01)$ and values management $(r(118)=.48, p<.01)$. Also, staff development $(r 118)=.26, p<.01)$ and empowerment $(r$ $(118)=.51, p<.01$ ) were found to have a positive and statistically significant correlation with respondents' perceptions of vision as a long term leadership task.

The findings correlate with the exposition in the literature study as well as the theoretical framework that all five leadership tasks contribute to the effectiveness of long term leadership and that vision encompasses the rest.

\section{Conclusion}

The perceptions of school staff on vision as a part of the long term leadership provided by their principals is reported on in this article. This investigation shows that the majority of respondents indicated that they "strongly agree" to "agree" that vision has an influence on the nature of the long term leadership provided by principals. The findings indicate that the vision of the principal impacts on the involvement of stakeholders, the effectiveness of school management and the quality of teaching and learning. A significant finding of this study indicated that there is a statistically significant difference between teachers' and other managers' perceptions compared to principals' perceptions on the importance of vision as a long term leadership task. Overall, the results show that the principals as well as other school managers and teachers were positive about the importance of vision in enhancing sustainable long term leadership of school principals.

Cautionary trends also emerged indicating that in some schools the vision does not focus on effective teaching and learning, that it does not serve as a guiding star in all school activities, that managing according to the rules is more important than visionary leadership, and that principals are not enthusiastic about the vision. From the results it is evident that long term leadership needs to be promoted by addressing these issues in some schools. Although respondent perceptions thus showed how important visionary leadership is in long term principal leadership, the above shortcomings that need to be addressed to move towards visionary long term leadership also emanated from the findings.

The results from inferential statistical calculations indicated that respondents' perceptions of vision has statistically significant correlations with vision communication, values management, staff development and empowerment as factors impacting on long term leadership at school level. This indicates that these leadership tasks together promote the long term effectiveness of leadership, and contributes towards validating the model of long term leadership used as the theoretical framework for this article.

One must view the present study cautiously because of limitations. The first limitation concerns the sample size which involved a small number of principals and teachers $(n=118)$ who participated in this study. Because of the restricted range of participants, in future research studies, the researchers should include a more diverse and representative sample of teachers and principals. The second limitation is the time factor. This study was conducted only on a once off basis and a longitudinal investigation might yield different results.

\section{Recommendations}

Although overall positive trends manifest regarding perceptions on principal envisioning in fulfilling their long term leadership task, there are also cautionary trends indicating problem areas that could be attended to in principal in-service training. These inter alia are:

- That the school vision should focus on effective teaching and learning 
- That the school vision should serve as a guiding star in all the activities of the school

- That principals should be enthusiastic about their school's vision

- That although rules are important in the principal's execution of management, the vision is the all encompassing focus of effective long term leadership.

For envisioning as a long term leadership task of principals to be effectively executed, the above recommendations need to be attended to. This should happen in the in-service training of principals in conjunction with those positive aspects emerging from the perceptions of the respondents and also stressed in the literature.

Although principals seem to understand the theory of visionary leadership, there are shortcomings in their application thereof. This has implications for the development of in-service course materials. There envisioning should also take the important place awarded to it in the model of long term leadership that served as the theoretical framework for the research.

Furthermore, the findings indicating a close statistical correlation between the various leadership tasks point in the direction of another recommendation, namely that the long term leadership model be used in the training of principals for effective, visionary, sustainable long term leadership. It is however recommended that more research focusing on the validation of the model be conducted, because this article did not specifically focus on this aspect and because of the limited number of respondents.

\section{Acknowledgement}

The valuable contribution of Professor PduP van Niekerk of the Nelson Mandela Metropolitan University, who assisted with the compilation and evaluation of the long term leadership questionnaire, is acknowledged.

\section{References}

Bass BM 2008. The Bass handbook of leadership: Theory, research, and managerial applications. (4th ed.). New York: Free Press.

Botha RJ 2004. Excellence in leadership: demands on the professional school principal. South African Journal of Education, 24(3): 239243.

Bush T 2007. Educational leadership and management: theory, policy and practice. South African Journal of Education, 27(3): 391-406.

Bush T, Anderson L 2003. Organisational culture. In: M Thurlow, T Bush, M Coleman (Eds.): Leadership and strategic management in South African schools. London: The Commonwealth Secretariat, pp. 87-99.

Bush T, Thurlow M 2003. Foreword. In: M Thurlow, T Bush, M Coleman (Eds.): Leadership and strategic management in South African schools. London: The Commonwealth Secretariat, pp. vii-viii.

Coleman M 2003. Theories of leadership. In: M Thurlow, T Bush, M Coleman (Eds.): Leadership and strategic management in South African schools. London: The Commonwealth Secretariat, pp. 155-172.

Crainer S, Dearlove D 2003. Business: The universe and everything. Chichester: Capstone.

Day DV, Antonakis J 2012. Leadership: Past, present, and future. In: DV Day, Antonakis J (Eds.). The nature of leadership. (2nd Ed.), Los Angeles:Sage, pp. 3-25.

Demartini JF 2002. The breakthrough experience. A revolutionary approach to personal transformation. Carlsbad, Cal..:Hay House.

Demartini JF 2008. The riches within. Your seven secret treasures. Carlsbad, Cal.: Hay House.

Department of Education 1996. Changing management to manage change in education: Report of the Task Team on Education Management. Pretoria: Department of Education.

Harris A, Muijs D 2005. Improving schools through teacher leadership. Berkshire: Open University Press.

Javidan M, Dorfman PW, Howell JP, Hanges PJ 2010. Leadership and cultural context: A theoretical and empirical examination based on Project GLOBE. In: M Nohria, R Khurana (Eds.). Handbook of leadership theory and practice. Boston, Mass.: Harvard Business Press, pp. 335-376.

Kleon S, Rinehart S 1998. Leadership skill development of teen leaders. Journal of extension 36(3):1-5.

Masuku S 2012. The instructional leadership role of the high school head in creating a culture of teaching and learning in Zimbabwe. DEd Thesis, Unpublished, Pretoria: University of South Africa.

McEwan EK 2003. 7 steps to effective instructional leadership. Thousand Oaks, CA: Corwin Press.

Murphy CU, Lick DW 2005. Whole-faculty study groups: Creating professional communities that target student learning. (3rd Edition). Thousand Oaks, CA: Corwin Press.

Mosoge J 2008. Talent development. In: J Heystek, R Niemann, J Van Rooyen, J Mosoge, K Bipath (Eds.): People leadership in education. Johannesburg: Heinemann, pp. 159-193.

Naidu A, Joubert R, Mestry R, Mosoge J, Ngcobo T 2008. Education management and leadership: a South African perspective. Cape Town: Oxford University Press.

Mail \& Gaurdian. 2011. SA education: The poorest choice, Why do South African children perform worse than those in poorer countries? 08 Apr 2011. http://mg.co.za/article/2011-04-08-sa-education-the-poorest-choice/ (Accessed 4 December 2013) 
Sterling L, Davidoff S 2000. The courage to lead: a whole school development approach. Kenwyn: Juta.

Steyn GM 2012. Professional development. In: GM Steyn, EJ van Niekerk: Human resources management in education. (3rd ed.). Pretoria: Unisa Press, pp. 41-68.

Van Niekerk EJ 2006. 'n Reformatoriese perspektief op die langtermyndimensie van die onderwyser se leierskapsrol. Journal for Christian Scholarship, 42(4):95-112.

Van Niekerk EJ 2008. 'n Reformatoriese perspektief op die korttermyndimensie van die opvoeder se leierskapsrol. Journal for Christian Scholarship, 44(3\&4):271-291.

Van Niekerk EJ 2012a. Challenges experienced by school managers in the Nkangala District, Mpumalanga, regarding the provision of long term leadership. Africa Education Review, 9(1): 174-190.

Van Niekerk EJ 2012b. Education leadership. In: GM Steyn, EJ van Niekerk: Human resources management in education. (3rd ed.). Pretoria: Unisa Press, pp. 292-324.

Van Niekerk EJ, Dube W 2011. The inadequate induction of novice educators: a leadership failure? Acta Academica, 43(3):243-265.

Van Niekerk EJ, Van Niekerk PduP 2006. Strategic management in South African education: The leadership dimension. Africa Education Review, 3(1\&2): 84-99.

Van Niekerk EJ, Van Niekerk PduP 2009. Managing change in education through a model of long-term leadership and short-term leadership. Journal of Educational Studies, 8(1):1-21.

Van Niekerk PduP 1995. 'n Evaluering van die doeltreffendheid van leierskap van boere in die Gamtoosvallei. MTech Business Administration, Unpublished. Port Elizabeth: Port Elizabeth Technicon. 